\title{
American Home. Missionary Letters From lowa
}

\author{
Edited by WALTER R. Houf
}

$M r$. Houf is presently an instructor in Social Science

at Drake University, and is working on a doctorate in history at the University of Missouri.

THE ORIGINALS OF THIS COLLECTION OF LETTERS ARE NOW IN the possession of Mr. Floyd E. Risvold, Edina, Minn. Part OF THEM ARE HEREWITH REPRINTED EXACTLY AS THEY WERE WRITTEN.

\section{(Part II)}

Continued from Summer, 1963 Issue

Mount Pleasant, Henry County, lowa ler.

Dear Sir Jan. $29^{\prime} 44$

The time has come for my first quarterly report. The county in which I am stationed is in extent 24 miles by 18 . Being of a rich soil well watered and timbered, it offers such inducements to both farmer \& mechanic, that it is already well settled for a new country, and is becoming more so every season. In this county there has been for nearly two years past no permanently settled minister either of the Congregational or the Presbyterian order. I am in the County Seat an incorporated town 26 miles from Burlington of some 500 innhabitants. A few years since there was a Congregational Church formed here of some 12 members but for reasons which were thought sufficient this some time since was abandoned and the church has died out. There is a Presbyterian (Old School) church here of some 20 members which since I have come here has had occasional preaching though it had been destitute for nearly a year previous. By the advise of brethren I am here as a sort of an experiment. I wish if possible to gather a church, and make this a centre of influence for the surrounding country. The peculiar obstacles with which I meet, as well as the peculiar encouragements also it will not perhaps be best for me to state in this report. If $I$ am successful you shall have the results, if not the reasons why. I can say however that on the whole the prospect is better than was anticipated. There are those here who want 
a minister who have been praying for, and are ready to receive one. Certain others who are not pious are interested in my remaining , and will aid in supporting a man with whom they can sympathise. One of the disadvantages under which I labor is the want of a house to preach in. I can have no apointment on the Sabbath excepting at 3 o'clock P.M. There are two points however 4 miles out in the country where I can generally preach in the morning. At one of these places I have organized a sabbath school which so far flourishes well. The average number of my hearers is about 50 , mostly young people, attentive and respectful to the subject of religion. There is doubtless an encouraging field of labor. The geratest obstacles are such as everywhere meet the Gospel minister-the influence of $\sin$ in his own heart and the hearts of his people. I intend soon to form a Sabbath school, a bible class and some other associations for the purpose of benefitting the people. But you want a report not of what I intend to do, but of what I have done, and this compels me to be brief at this time for much of my work thus far has been that of preparation and outliving certain prejudices that exist in some minds, and gaining the confidence of the people. The work Dear Sir which I have undertaken, under the patronage of your society, is by no means a small one.

Yours \&c. Ephriam Adams

P.S. I can probably have a house to preach in in a month or two. The Methodists are most numerous in this town they have just completed a house of worship. The Campbellites are also building a church. They number 200 but their members are gathered in from a distance of 12 miles around. There is a society also of Cumberland Presbyterians.

Gent.

Dubuque Mar 25, 1844

Since my last report nothings of : special interest has occurred among my own people. Our congregations continue about the same as heretotore \& I think the cause of Cht. [Christ] is progressing among us. There are some encouraging indications of a revival. Some of my hearers appear to be deeply affected by the truth \& some I hope have been recently converted. 
During the past quarter I have been almost wholly occupied in labor in protracted meetings. About Christmas ,the session of $\mathrm{Br}$. Kents $\mathrm{Ch}$. at Galena [Illinois] sent for me to labor there, as their pastor had been providentially called away for a season \& there was an evident awakening in the church and congregation. I was just recovering from a fit of sickness but the call was so impressive that I dared not decline it. I therefore went \& commenced preaching to large congregations \& continued my labors daily for three weeks at the end of which time upwards of 20 individuals had publickly expressed their anxiety for salvation. I was then obliged to leave to fulfill a previous engagement at Platteville [Wisconsin] where a revival had commenced \& where I preached a little more than a week \& where were numbered from 40 to 50 converts. After a short interval I was again called to Galena where I labored two weeks more with much interest; \& last week I also spent in the same place. Other ministerial brethern with the pastor filled up the intervening time so that steady preaching was maintained there for, I think, about 9 weeks; $\&$ as the result 76 have united with the ch. \& some 30 or 40 candidates more I think have been examined approved. The work in many erspects was remarkable; pervading the city to a degree hitherto unknown there. Upwards of 200 have united with the Methodist \& some with the Baptist ch. likewise. But as Br. Kent intends publishing a particular account of the work, which you will doubtless see, I shall add no more. I have said this much as you are entitled to know how my time is employed. In my absence my pulpit has been supplied so that our meetings here have been uninterrupted with the exception of one Sabbath when Providence interposed to prevent the brother from reaching here who started for the purpose of supplying my place.

I have now several calls to assist my neighbors \& brethren in protracted meetings \& shall as far as possible comply with them.

The quarter now closed ends my missionary year. My people are now circulating a subscription for my next years support, but have not progressed far enough to determine 
what aid they will be compelled to ask from your Society. I have urged \& they feel the imortance of relieving you to some extent from contributing to my support-but at present our church is poor \& we depend on the community. We may be obliged to apply for the same sum this year that we did last \& if so we hope it will not be withheld. But we will do with less if we can. From present prospects we shall at any rate relieve you somewhat in another way vis by our contributions. The past year I have not recd. $300 \$$ from my people \& had I not recd something in Galena, I should not have been able to meet my necessary outgoes. As it is, the Lord has provided for me. Our application for aid will soon be sent on.

Respectfully Yrs.

Jno. C. Holbrook

Dubuque, I.T. March, [27] 1844

Dear Sir

The Rev. John C. Holbrook one of your Missionaries having preached in this place to the satisfaction of the church and people, the church have voted him a unanimous call to labour here in the ministry, with a salary of six hundred dollars, which is the least sum that we think would afford him a comfortable support in this place. We wish to procure the aid of the A.H. Missionary Society to the amount of two hundred and fifty dollars. The name of the Church is the Presbyterian Church of DuBuque. (Iowa, Ter.)

The number of communicants twenty seven. There is in this place a large Catholic Church a Baptist Church and a Methodist Church. The sum of Three Hundred and fifty dollars is the most that we can raise towards his support this year. For further information relative to the important situation we occupy, we would beg leave to refer you to the Revnd Stephen Peet. His salary should commence on the 20th day of March 1842.

We are your Obnt Servants

E. Lockwood

Samuel H. Hicks [?] Elders 


\section{Dear Sir}

My statistical Report must necessarily be [illegible] as the time in which I have been in my field is so short.

1. My church is called the First Congregational church of Cascade-Dubuque County lowa Ter. My address is Cascade Dubuque Co. Iowa Ter.

2. A church has been formed of 12 members all except two had letters.

3. The Sabbath school I have not yet formed I have ascertained however that there will be about 40 scholars

4. We have no library but suppose there is one on the way if you have presented my application to the A. [merican] S. [unday] S. [chool] Union-

5 . One hundred names have been added to the Temperance Pledge

We hope to erect a church during the present Summer \& trust we shall make a small contribution to your Treasury soon though we shall be obliged to contribute "of our poverty." My people are all beginning to live. They are not able to provide comfortably for themselves but the time will not be far distant when they will be independent of your aidAn increasing interest is manifest among the people in religious things $\mathrm{My}$ Congregations are increasing in members \& I think I have discovered some evidences of seriousness. I expect to hold a protracted meeting about the middle of April with the help of Br. Holbrook

There are six points where I preach occassionally-at each place there can be a small Sabbath school organizedWhether I shall be able to keep them all in existence will depend upon my getting suitable persons to take charge of them in my absence. This is very difficult. There are very few pious laymen here to take the charge of S. schools \& prayer meetings. A few such men scattered over this country would be of invaluable service to your missionaries-I hope much will be done the present summer to plant colonies of pious families in this Territory

I wish some method could be adopted by which this subject could be laid before the churches of the east. The plan of 
colonizing for the purpose of establishing schools \& churches I perceive has begun to excite some attention among the good people of the east. If it could be successfully carried out it would hasten very much the triumph [of] the gospel in this valley.

\section{Dear Sir}

$$
\text { Yours in the gospel }
$$

\section{Edwin B. Turner}

Springfield, Iowa, April 1, 1844

I have two churches under my care-one in Andrew, Jackson Co. Iow. consisting of thirteen members. The other at the Forks of the Maquoquita [River] Jackson County consisting of nine members. My post office address is Springfield. Jackson Co. Iowa.

2. There have been I think several cases of conversions. They are scattered over a large field. Could they receive the continued constant \& frequent attention of your missionary I should have less reason to fear reporting them as hopeful.

3. Two have been added to the Church at the Forks by letter.

4. I commenced a Sabbath School at this place Sunday before last with fifteen scholars. We shall have forty here in the summer. If I can procure books \& teachers there will be two hundred Sabbath School Scholars in this country. I made a request thru Mr. Patton on you for a library from the A.[merican] S.[unday] S.[chool] U.[nion] I hope to receive the books early in the Summer.

5. I have: held one Temperance meeting.

6. I have organized one church at the Forks.

7. Contributions have been raised for the County Bible Society to the amount of fifteen dollars. We are now erigag[ed' in] distributing by Sale \& by donation a large supply of Bibles [and] Testaments rec'd this winter from the A. [merican] B.[ible] S. [ociety]

8. I am on the eve of commencing subscriptions for the erection of two meetings houses-one of them will be of log

I have held three sacremental seasons the last of these was held yesterday. Br. Holbrook assisting me \& preaching in connection [with them] six sermons. Very wet weather \& 
the heaviest prairie wind I have ever experienced \& the bad state of the roads prevented a large attendance until Saturday \& Sabbath when one little log house was as crowded \& contained as many immortal beings in proportion to the size as any other building ever did.

I have now been in Commission five months. In that time I have preached a great deal. I feel that I have not labored in vain. I have been as happy in my work as I know I should have: been had I tarried in the East. The Emigration is pouring in. This year more new faces will be seen in Iowa than were ever seen in any one year before. $O$ send also the Ministers of Christ.

$$
\begin{aligned}
& \text { Yours in the labors of the Gospel } \\
& \text { William Salter }
\end{aligned}
$$

\section{Tipton Cedar County Iowa May 2nd 1844}

Since I made out my Annual Report I have been absent from my field of labor between 3 and 4 weeks to attend an important meeting in the Southern part of the Territory. During my absence I preached 13 times besides delivering a Temperance lecture. I preached also. for the first time in this Territory in a meeting house, a real genuine meeting house, with a steeple to it. This you may be assured was something new, and as I rode up towards Black Hawk and saw the turret of a church in the distance the sight was new and interesting. I do not know that I have recently seen anything to call up before my mind more vividly the scenes of the East than this unless it be the appearance of the Congregation of Br. Turner at Denmark. Enter that Congregation, as I did to preach a preparatory lecture, and you would suppose yourself again in New England amidst its granite hills. This people have emigrated directly from New England, and have not sojourned, as is usually the case in Ohio, Indiana or. Illinois, or in all three of these States. At the present time, though one unacquainted with the fact would suppose the contrary, the Eastern people are to be found in the Southern part of the Territory much more than 
is this region. In the towns, along the rivers where there are dams and mills you will find them.

I have been endeavoring to prepare things here for the formation of a church, and intend on the next Sabbath to organize one. There are upwards of 12 individuals in the County who ought to be connected with it We labor under the disadvantage of being too much scattered to come conveniently into one organization.

At present I occupy the jail for a church, and preach here 2 Sabbaths out of 3 Could you have been present on the last Sabbath, and seen an audience of 150 assembling for worship, you would have felt that it was not in vain to station a preacher of the gospel here. It must be borne in mind, however, that a regular attendance at the house of God upon principle is something yet to be learned here. Preaching and the management of steamboats are conducted here on something of the same plan in one respect. The boats frequently "get up steam" just to draw aboard and secure passengers, where there is no real intention of starting. And so preachers,' if they do not resort to anything novel designedly to secure an audience still, if there is anything novel about them, accomplish the same object. A man ought not here to be unduly' encouraged by the appearance of a good audience on one Sabbath, nor discouraged if on the next they should absent themselves to hear some other new thing:

Cedar County is 24 miles square and Tipton is at the geographical centre. It is a point which we ought to occupy: We are here only 25 miles from Bloomington [now Muscatine] nearer the market than Linn Co. which has rapidly filled up. There are probably about 2000 people in the County and though there has not been such a super abundance of timber, as to induce a rapid immigration; still the fertility of the soil, the proximity of the market, and the number of mills upon the smaller streams in this vicinity will yet bring in a good population. There is not probably in the Territory a situation more favorable to health than the County Seat. The appearance of things indicate that there will one day be a abeatiful town here, where 4 years ago 
was an unbroken prairie. The people in this region attend the preaching of the gospel well. Within 2 or 3 years there has been a great advance in morality. But still could you on the last Sabbath have witnessed the boys playing, fighting, and swearing in the streets you would have felt the necessity of a Sabbath School. I have been informed that 2 libraries of the Mass [achusetts] S. [unday] S. [chool] S. [ociety] have already arrived in the Territory for me, one of which I hope to use here. I preach at a number of points in this County as well as in Johnson County.

With regard to the ability of the people to suport the gospel I will state one or two facts. The deacon of the church at Solon has during the last winter lived in a house of his own. He and his family have passed the winter in a shantee constructed of slabs, just large enough to hold a bed, a cooking stove and a place to eat of 4 or 5 feet square. This is of course surely for a time, till the square log house to which this is an addition can the next season be completed. In a few months he will be in a comfortable situation.

The only copy of the "Home Missionary" ${ }^{6}$ except my own in Cedar County is sent to a good lady 7 miles South of this place. She could not for a number of weeks take it from the [Post] Office recently, until she persuaded the Post Master to take the postage upon it in corn. Now of course if there is any one in the whole region who feels any interest in my operations, these are the inviduals.

\section{Yours}

Ebenezer C Alden Jr.

\section{Dear Sir,}

Keokuk Lee County Iowa July 151844

Another year of my missionary life and labours having come to a close, I am reminded of my duty to send in my quarterly report. Indeed my whole missionary life through near nine years; has been marked by a succession of painful events, which have kept my heart continually bleeding, over

6 A monthly magazine used to disseminate information about the activities of the missionaries in the West. It contained copies of their reports or excerpts from them. The hope was that this would arouse interest in the missionary work and attract support for it. 
blighted hopes. in the fall of $1835 \mathrm{I}$ exchanged the life of a New England pastor for that of a missionary to the west. Could I then have seen what a host of trials were comeing upon me, I should have needed the intercession of the Savior, that my faith might not fail. While I have suffered an unusual share of the ordinary trials and privations of western missionaries; in the opinion of my brethern, death has been multiplying his victims from the members of my family; till I have almost been writen dessolate in the earth. Nine years ago my family numbered 5 persons. Since then 3 have been added to the number, but where are they now. 2 daughters cut of $[f]$ within a few weeks of each other, sleep in Indiana. Another promising daughter was suddenly cut down in Illinois but a few months before I came here, and in less than one year I have twice been called to deposit in the grave, those who were dear to my heart. Last fall almost immediately after I came here, the grave closed its mouth upon a dear Son; and now to fill up my cup of sorrows to the brim, the Lord has by a Sudden an[d] unsuspected Stroke, removed the dear partner of my toils and Sorrows. On the 26th of June when no danger appeared to threaten us, and when we were fondly hopeing to see our broken household soon inlarged; my poor wife was suddenly taken with terrable convulsions, and in the Space of 8 hours her clay tabernacle was demolished. The only remnant of my household that remains consists of 2 sons, and one of these by a fit of sickness has been rendered a cripple for life. But shall a living man complain? God forbid. No, the ways of God are right whether we can comprehend his designs or not; and being assured of this fact, I hope I can say "Though he slay me yet will I trust in him." God grant that these trials may tend to purge me from all my dross, and to make me more useful, as a missionary of the cross. In reviewing the results of my labours for the past year, though I have no triumphs to record, I have every reason to be encouraged. Indeed I have been very happily disappointed in many things. Could you see our place of meeting crowded with attentive hearers, in every nook and corner; and remem- 
ber that one year ago the Sabbath was almost universally desecreated in this community, you could not avoid the conviction that an influence has been felt. No one doubts that a grandual, though marked change has been taking place in this community; and that there is less open wickedness; especially on the Sabbath. The want of a Suitable house to meet in, is daily more felt, and no one doubts that our congregations would be twice as large as they are, had we comfortable accommadations. I hope that something will soon be done to get up a house.

Desireing an interest in your prayers, that God may Sanctify me in the furnace of afflictions; I remain yours, in Christian bonds

Daniel Jones.

P.S. a draft for the past quarter will be acceptable when convenient.

Iowa City Sept 51844

Dear Brethren by a kind Providence my. life has been spared to close the labors of an other year of Missionary labor My own health and that of my family has been good this season

During the last quarter four individuals united with our church by examination, three of them heads of families the other one is a young man who promises to be useful to others living a few miles from the city have virtually united with us on certificate-making in all seven persons who have united with us this summer This appears to be but a small movement made on the enemies ranks, but we bless the Lord and take courage, feeling these are monuments of his love and tokens of his passion.

That you may better understand the moral state of things in Iowa City I make to you the following statement communicated to me by a minister of the Methodist Episcopal Church in this place who preached for me once or twice during our last communion season when the persons mentioned above were united to the Church.. Viz that there had not one person on the profession of their faith in Christ for the first time been united to any other evangelical church in this City during the summer. 
The Baptist Church had a protracted meeting of six [illegible] days without any success

The Methodist Conference was held here for several days and passed off without success

The Protestant Methodist and Old School Presbyterians have been equally unsuccessful as I have been informed yet Sabbath preaching in this place is well attended The lovers [of] the world must engross the hands of someone[?] I have preached during the summer regularly in this City at eleven oclock, attended a Bible Class at $1 / 2$ past and then preached at 3 oclock, in the same place out in the countrythe members of our church generally and a few others were much engaged in the [Bible] class.

The openings round about in the vicinity of this city for evening preaching have multiplied and invitations to enter towns and preach the Gospel have been repeatedly surprising.

The last quarter of my commission terminated on the last day of August 1844 - and this letter contains my report of that quarter according to the terms of my commission I wrote you to send us a church bell worth $\$ 100.00$ and charge to my account. The bell has not arrived nor any communication on the subject. I afterwards requested you to send me the balance due on the end of my next quarter, $I$ have as yet received no answer.

I am preparing to attend the meeting of Presbytery and the Congregational Association of Iowa Territory next month. The Churches of this Territory are steadly and permanently gaining strength but some of them enjoy a revival

Give credit to the Iowa City church for five dollars contributed to the American H. M. Society and paid to me

Wm W. Woods

Fox P.O. Davis Co. I T Jan 30th 1845

Dear Brethern

In making this my first report in the new year, I would commence by recording my gratitude to Almighty God, and under Him to your Society for their generous aid in supporting the Gospel, in this remote part of our common country. 
It was under the auspices of your Society, that the only church of our order in the Ter. west of the Des Moines, was organized, some two or three years ago; and had it not been for the fostering hand of the same Soc. it must have remained, until this time, destitute of the regular ministration of the word. Our meetings continue - much as they have been. Oweing to the great number of sects, and to the sectarian feeling that prevails, my congreg[a]tions are unusually small. The majority of professors are members of the Methodist Church, and but few of them are seen at our meetings. They have their class meetings at the same hour that I preach and I have reason to believe that circuit preachers encourage such a course. The Mormans have meetings occasionallythere being one family of them two miles distant. They have had but little influence, as a sect, in this vicinity.

The Campbellites hold their meetings less frequently in this neighborhood. Their principal preacher in this Co. having held meetings for some time near one of my preaching places, and having made no converts, at length seemed to grow impatient, and preached his farewell sermon.

Only one S. School, of about 25 members is continued through the winter: In this, there seems to be a considerable interest. By the generosity of Christians in the East we have received, since my last report, a box of books from the A.[merican] S.[unday] S.[chool] union. As I hope to have 6 or 7 schools in the Spring, these will very seasonable. I have cheering evidence that the S.S. books are doing much to create a taste for reading, and awaken an interest in reference to $\mathrm{S}$. Schools. Had we a few more faithful and competent teachers the usefulness of our schools, would, undoubtedly, be greatly increased:

I have established bible classes at my principal stations for preaching-4 in number-which are pretty well attended.

Since my last report, another day school has been opened in the Co making now two in the Co We hope there will be one or two more in the Spring. It is sad to reflect, that such is the need of suitable teachers, that one is now employed, who is said to be very profane an infidel, and scoffer. Two families have taken their children from the school. 
Much excitement has existed among the people in regard to the land sales that were expected to come on in Feb next. Not one in 10 or 15 was prepared to pay for his land, and much anxiety was felt. But at length the news came that the sales were indefinitely postponed-news most welcomed to the majority, but not so to those who were prepared to enter their land. There are many who have less money now then they had 3 or 4 years ago, when they first came to the Ter. as they have not produced enough from their farms to support their families. To put a few acres under cultivation, and fence it, is quite an undertaking for a poor man, who has no capital to commence with. Only one member of our church at Troy, would have been prepared to enter any land if the sales had come on, as was expected.

The county seat of Davis, [Bloomfield] is gradually increasing in population, though I think it will be some time before it will be very considerable. There are now 7 families. I preach there once in four weeks, and in the Spring, except to, once in two weeks. The Methodists and Baptists also hold meetings there. But very few of the inhabitants seem religiously inclined. Much whiskey is drank in the place, but most of it, I believe by individuals from the tract of country bordering on Mo.

Our people have commenced building a log school-house in Troy, which is also to be occupied as a house of worship.

Yours in the fellowship of the Gospel Wm A Thompson

Sac and Fox Agency, Wapello Co. [Iowa] 28 Feb. 1845

I requested the congregation to which $I$ preached on the first Sabbath of the year to unite their prayers with those of others for the out-pouring of Holy Spirit. This was at Eddyville, a little town on the Des Moines in the extreme corner of this county nearly 20 miles from this place. Here there had been for sometime several Christians of like sympathies, but no church with which they felt like uniting, and some frankly confessed that they had become so coldhearted and worldly that they were unworthy to unite with any church. Six of these, four males and two females, have since united in 
the organization of a Congregational Church and established a weekly prayer meeting and a Sabbath School. Others have been interested and revived and expect to join with us after time for reflection and self examination. One was added to this church on the last Sabbath, a young man who had been known as one of the wildest and most reckless in the neighborhood. This young man and a brother attended meeting the first Sabbath of the year and heard a sermon from this text; "This year thou shalt die, because thou hast taught rebellion against the Lord." A little more than two weeks afterwards this brother, while hunting was accidently shot in the breast and died within two days, but not until he had urged his brothers, sisters and friends to repentance with a power possessed only by one standing on the brink of the grave. Two confessions have already, as we hope, been the result and other good fruits we shall still look for.

Strange as it may seem in connection with the utmost apparent recklessness, these two young men had been accustomed to talk with each other seriously on the subject of religion and sometimes pray together and the survivor informs me that never after a day spent in the most open profanity and wickedness did he suffer himself to close his eyes to sleep until he had repeated the prayers which his mother had taught him in childhood. On a visit to his father's family I witnessed an incident as pleasing as any that I have seen in the West. It was a little girl on Sabbath evening sitting on her mother's knee, and reciting in the form of a cateshism, [catechism] a system of theology which by its clearness, completeness and truth could secure the mind forever against many of those evils and fallacies cherished by some who profess to be [illegible]. An incident like this would hardly fail to remind a descendent of the late Puritans of other days and other scenes.

Wapello Co. is 24 miles in length by 18 in breadth, and is nearly bisected by the Des Moines, which enters it at the north west comer and leaves it at the south east. There are in it three important places for preaching - the Agency, Eddyville and the county seat (Ottumwa) and a neighborhood around each of these abundantly large enough to oc- 
cupy all the leisure hours of any minister in visiting, lecturing forming temperance societies establishing Sabbath Schools etc. Directly west of this is another county (Kishkekosh) [now Monroe] of the same size and perhaps equal in fertility and beauty though not yet so well settled. If you were to send one, two or three more ministers into this county and the adjoining they would find abundantly enough to do if they had a mind to work.

This will, before long, be necessary to carry out the plan under which I have labored and which you have approved. The population along the Des Moines is increasing continually. The people are generally so well pleased that they write back to the friends whom they have left behind encouraging them to come out. They seem to regard it as a land "flowing with milk and honey, which is the glory of all lands. interesting letter from one of the Secretaries.

Since my last report I have received my commission and an interesting letter from one of the secretaries.

\section{B.A. Spaulding}

Davenport Scott County Iowa March 31-45

Dear Brother

Though I have been in this place only since Nov. last yet I will give you the statistics of this church for the last year.

1. The Davenport Cong'tl Church. Davenport Scott Co. Iowa. My Post Office Address Ephraim Adams, Davenport, Scott Co Iowa

2. Number of hopeful conversions 0

3. Number added to Church by profession---0

4." " " " " " " " letter -

5. Number of sabbath school \& bible class scholars 36 (26 in school 10 in bible class)

6. Number of Volumes in S. S. Library - - - 110

7. Number of temperance subscribers - _- 250

8. Number of churches organized in the year-_-_ 0

9. Contributions Since 1st of January For. [Foreign] Miss. [Missions] $\$ 6.50 \mathrm{~A}$ neat and commodious house of worship completed Nov. last. Congregations good. 
In respect to the Territory in general I cannot give you exact statistics for we have not as yet had reports of this kind made in our Associations. We have made arrangements for this however at our next general meeting in June. So far as I have the means of knowing there are under the care of your missionaries in the territory 30 churches embracing 673 communicants. These churches are situated as a general thing in the most important towns and promising settlements so as to form centres of influence for the region about them.

Temperance too is promoted in every way as the handmaid of religion. Tis true indeed that the sad effects of intemperance are in many places too visible among us. Yet there are some prairies here never disgraced by the reel of a drunkard, some settlements never cursed with the whiskey barrall, and others that having felt the curse have banished it from their midst. Nor is the cause of popular education by any means forgotton. Many are its friends here. In the infancy of things we have not of course any regular system of education already established, but the subject is talked of, steps in reference to it have already been taken in the legislature, and it is hoped that as Iowa will probably soon be fairly reckoned among the sister states, she will also be reckoned among the number of those that have in successful operation something like the common school system of good old New England. Hitherto we have for the most part preached in public halls, in court houses in schoolhouses in farmhouses and sometimes in the open air. With few exceptions we have been destitute of houses built for religious worship. This has been a serious difficulty. There is a prospect however that in a short time this difficulty will in a great measure be aleviated. 10 churches if not more most of which are already in progress will probably be completed the ensuing season and dedicated to the worship of the living God. Thirty churches and somewhat less than 700 communicants may seem like the day of small things in such a Territory as ours embracing a population of 80,000 souls. Many are the families found destitute of the bible the children growing up in sin and ignorance too many are the settlements where the gospel is seldom preached. Infidelity has indeed in some 
parts been checked by the fall of its leader but it yet remains. Stubborn prejudices are everywhere to be met in these mixed communities; errorists are as busy as ever while there's scarce a town of any importance along the banks of our noble river where the man of Sin [Catholic] has not secured a permanent foothold. A fact which of itself reveals to us the wisdom and necessity of speedily giving the gospel to this whole territory for Rome shows her wisdom in nothing more then in the choice of her locations. That she makes large calculations upon this region is but too evident.

As to our "Iowa band" 7 I will say but a word. Nor would I say even that had you not requested it. Enough has already been said of it in distinction from the rest of our brethern in the West \& and it becomes us especially to be silent.

Yours, \&c.-Ephraim Adams

Brs. Badger \& Hall,

Montrose, Lee Co. Iowa, July 7. 1846.

. . I moved with my family, (wife \& 2 children) to this place last spring. Calling on some of our old friends here, we unexpectedly stoped here in the midst of the Mormons. We arrived about $t[$ he] middle of last April, when the Mormons were moving towards the Rocky Mts. very fast \& many new settlers coming in. The same was true on the other side of the Miss.[issippi] river in Nauvoo [, Illinois] \& the surrounding country. After consultation among the friends here, it was thought very important to have preaching as the change was making-I was urged to stop, \& finally concluded that it was duty to do so, although the prospects for support

7 This is the fairly well-known group of young men who came to Iowa in 1843 to supply leadership to several churches in the territory. The idea for such a venture developed among some students at Andover Theological Seminary in 1842. After contacting the American Home Missionary Society for advice, and with its promise of aid they left for Iowa October 4, 1843. The group originally included Ephraim Adams, Harvey Adams, Ebenezer Alden, Jr., William Hammond, James J. Hill, Horace Hutchinson, Daniel Lane, Erastus Ripley, Alden B. Robbins, William Salter, Benjamin A. Spaulding and Edwin B. Turner. All but: Hammond, Hill and Ripley traveled together, arriving in early November; 1843. Hill and Ripley came out in the spring of 1844 and Hammond, because of illness in his family, had to abandon his plans for service in Iowa. Rev: Ephraim Adams, The lowa Band (rev. ed., Chicago, 1903); pp. 3-27; William J. Petersen, The Story of Iowa (New Ÿork, 1952,) II, 681-683. 
were poor. About this time I saw $\mathrm{Br}$. Asa Turner He advised me to stop, \& said, no doubt the H.M. Soc. would aid in support. In the course of 2 or 3 weeks, Br. Reed, your agent, came along; he said I had better stay, \& if proper application was made out for aid, he would sign it. We both went to Nauvoo \& found that a Mr. Fruness[?] from Quincy [, Illinois] had purchased property there with several others, mostly Presbyterians, \& had engaged Rev. Mr. Marks of Quincy, about to go to the Gen. [eral] As. [sembly] to get a minister for them, but wished me to supply them once each Sabb. till that time. Br. Reed advised me to do so, I have; Last Sabb. a Mr. Mason, late from Lane [Theological] Sem. [inary, Cincinnati, Ohio] came there as a candidate. I expect to go there no more.

The attendance here is rather better than in Nauvoo, but not very good in either; but perhaps as good as ought to be expected considering the circumstances, the excited state of the community \& the withering effects of Mormonism. Things are, however, settling down \& the prospects for doing good directly are becoming more \& more favorable both here \& in Nauvoo. There is no church organized in either place. It was the intention of those professing religion \& others disposed to unite, before this time, to make a formal application to the Home M. Soc for aid; but no one has taken hold of it, in part, because favorable changes are continually taking place, so delay will increase the amount subscribed here. I feel a delicacy in pushing it. The principal reason, however, is because I had my horse, Saddle, \& bridle stolen some 4 or 5 weeks since, which deprives me of the privilege of visiting \& becoming intimately acquainted with the new comers, \& thus collecting the facts necessary for an application. As I am not likely to get my horse again (he has gone to California) \& have but 125 in the world to purchase another with, I do not know when the facts for application can be obtained. Horses are scarce here \& none to be borrowed. I presume, however, application will be made as soon as possible, \& it will be very desirable, (at least to me, as I have only a log cabin 18 by $16 \mathrm{ft}$. with no chimney to live in, \& as I must build a little addition this fall or suffer in winter,) that the 
Commission, if granted, be dated back to last April, the time I commenced preaching here. On account of this great delay I felt it important to write this letter by way of anticipation.

I will add, this whole region for 10,15 \& even 20 miles around on both sides of the river was filled up, with few exceptions, with Mormons. Leaving out Br. Jones of Keokuk who has been here a few times, there has been no preaching whatever in this place or Nauvoo for years, except Mormon, which is, most of it, blastphemy. When I came here there was no preaching of any kind here or within 3 or 4 miles. Now I preach twice every Sabb. \& the Methodists occasionally. There are no families here or very near here but presbyterian \& but few of them, though most of the leading men in the place are favorable \& desire to have presb'n preaching \& a reform in Society. The soil in this region, the half breed tribe section, ${ }^{8}$ cannot be surpassed in richness, \& when it comes into market (which is supposed to be soon) will be filled up \& improved very rapidly. This point on the Miss. [issippi] at the head of the rapids is in many respect considered very important.

I close with a few things about Mormonism, which is only another name for black-legism, especially as it respects counterfieting \& horsestealing, \& general corruption of morals.-

Profanity, Sabb-breaking \& unlawful intercourse between the sexes, ( which is, in Mormon dialect, spiritual wifery, \& a doctrine of their church) can't be surpassed by any set of people christian or heathen- These things I have seen with

my own eyes \& heard with my own

ears from their own lips. They are

true of a majority, I may say \& in truth, of a great majority,

8 This refers to the segment of land, approximately 119,000 acres in size, set aside for the ottspring of white men who had penetrated into the Indian territory, and their Indian women. The half-breed tract, as it was usually called, lay within boundaries formed by the Des Moines and Mississippi Rivers from their junction, north to an east-west line running from Fort Madison to a point about one mile below the present site of Farmington. This triangular-shaped area roughly corresponds to the portion of Lee County which projects below the main body of Iowa. Though reserved, pressure by the whites eventually led to their penetration and settlement of the tract. Charles R. 'Tuttle, An Illustrated History of the State of Iowa (Chicago, 1876), pp. 70-73. 
though there are a few honorable exceptions. Swearing, I have been told by them when [illegible] them was aa part of the Mormon religion. Working on the Sabb. they say is right especially when preparing to go into the wilderness. Stealing they contend is not wrong, for they are God's people, \& he has given the earth (which is his) to his people, \& they have a right to it.

Some 12,000 or 15,000 have left, they are still going- There are perhaps 500 or 600 yet in Nauvoo \& some few scattered around the country. It is hoped that they will all go but it is to be feared that they will not all go for some time. Many of them, especially those who come from other parts of the country \& other countries, (for all come here to $\mathrm{N}$. [auvoo] to start with the rest) deny \& denounce Mormonism, when they see what it is at head-quarters, where they have been trained, \& instructed by the prophet himself, Joe Smith. These are generally honest, decent, moral \& sincere persons, but have been deceived. They are falling to pieces \& will soon come to nough $[t]$. They contain no elements but those of destruction, they will die of themselves, if left alone. They think they will soon come back \& take possession of their splendid temple \& their lands, but not till the gentiles are all destroyed, which will be in 3 or $4 \mathrm{yr}$.

Yours respectfully \& in Gos. [pel] bonds, G. C. Beaman

\section{Dear Sir}

Keokuk Iowa July 20th 1846

Such is the state of feeling here amongst some of our citizens and such has been their action that it is thought prudent to lay the facts as nearly as possible before you, that through you the society may know our position as a church and according to the direction of the church we make this communication.

In the early part of last month a report was industriously circulated in the village, "that the presbyterian church of this place intended to change their organization and form a congregational church and that with the exception of a few 
members, they were all desirous for the change' this report was believed even by many members of the church and as the report obtained belief, the confidence of the publick in the consistency and stability of the church was weakened upon being informed of the report, Bro. Jones immedately saw its tendency, and on the succeeding sabbath published a call from the pulpit for a meeting of the Church and congregation, to consider the propriety of renewing the Call for his services as a missionary amongst us, and also such other subjects as might be important to the interests of the Church, mentioning the report expressed above. The Church met with many of the congregation, \& after organizing the object of the meeting was called for and Mr. Wicoff stated the object to be, to consider the propriety of renewing the call for Bro. Jones's services amongst us; upon suggesting that the truth of the said report was also to be considered, the introduction of that point was warmly opposed by Mr Coleman who was joined by $\mathrm{Mr}$ McCane, and an animated debate ensued during which it was distinctly announced by Messes. Coleman and McCane, that Mr. Jones was not the choice of these people and he could never build up a church in Keokuk, However it was finally decided that both of the above points should be considered. In consequence of the above statements by Messes. Coleman and McCane a motion was made, whether the members of the Church should by vote say whether Mr. Jones was acceptable to them; this motion was also opposed by $\mathrm{Mr}$ Coleman \& Mr McCane on the grounds that the church should not express an opinion at a meeting of the Church and congregation. Upon putting the question it was decided that it would be proper for the church to vote. Immediately upon which; Mr Coleman and Mr McCane in a disorderly manner left the house, drawing their adherents as we supposed; the entire church remained and many of the congregation; and upon putting the vote upon the main question their voice was unanimous, that with $\mathrm{Mr}$. Jones they were satisfied; this vote was taken, by ballot. Upon the second question to be considered (whether the church wished to change her organization, the vote was then 
taken, and was unanimous in favor of preserving the present form of the government of the Church. Such was the insidious nature of this report, that each member voted suspecting that his brother member was disaffected.

The Church, being publically informed by Mr. Coleman and $\mathrm{Mr}$ McCan that $\mathrm{Mr}$ Jones was not acceptable to the people of Keokuk, they thought it their duty in justice to him, the Church and the A.H.M. Society to ascertain as nearly as possible the facts in the case, and appointed a committee for that purpose upon visiting upwards of One hundred persons, of the whole number upwards of Two to one were in favor of retaining Bro Jones: and of the church going people, who are presbyterians in their feelings there is a majority of nearly six to One in favor of renewing his appointment, who believe under all the circumstances a change would not be a benefit to the Church. The committee at a subsequent meeting of the Church made the above report upon which the church voted Unanimously that an application be forwarded for the reappointment of Bro. Jones, for our supply here; at the same time voting, that the society be made acquainted with all the facts. Since this church meeting we are informed $\mathrm{Mr}$ McCane has been industriously circulating a paper for signatures with the intention of informing the board of missions, that the committee appointed by the Church, had not made themselves acquainted with the facts - We do not know whether Mr McCane will continue his hostility in this form.

Mr Web a member of the Church but not present at the Church meeting believes a change would be for the advantage of the church. Mr Troy also who is a constant attendant, a profesor of religion, but not a member in our Church also thinks a [change] in our Missionary will be a benefit to the Church here: Others who are general attendants upon the publick servises of the Church and Dr Hoover and Wife and Mr Putman and Wife who express the intention to join the church at our next Communion by letter think a Change at present will be directly injurious by giving to a few individuals, restless and it is feared graceless, a victory over the Church. The general feeling is expressed towards 
Bro Jones is highly reputable, and is evidence that he has well sustained the high Christian character demanded by his station. In the man all have the utmost confidence, and his unremitting exertions are generally admired, and many believe he has been very useful. For the last 3 or 4 weeks Mr Coleman \& Mr McCane have appointed separate prayer meetings; with the object as we suppose of forming a nucleus for another church. There is no facts that have come to light that in the judgement of the committee can either directly or indirectly be so constructed as to cast the least censure on Bro Jones. The position of Mr Coleman is known, and $\mathrm{Mr}$ McCane has lately withdrawn from the Church, and was refused as we are informed admission into the Methodist Church to which he applied. The Church is at peace but weak; and under the circumstances as they exist here for the advancement of her interests not only prayerful care but advice is important. We have thus presented the whole case before you believing that through the grace of God the course the society will pursue will advance the cause of Zion here

Dear Sir

Jno. M Young

Peter Wicoff

Keokuk Iowa July 20th 1846

The time having Expired for which the Rev. Daniel Jones is stationed here as your missionary. The Presbyterian Church of Keokuk at a Church meeting for the purpose, unanimously voted that application be made to the American Home Missionary Society for his continuance with us as your missionary and have appointed us a committee to apply to the society for a new appropriation for his support the ensueing year. The Church numbers at present Fifteen communicants five of whom are males; our room for worship is small but generally well filled, and is sometimes crowded. The Methodist Church which is contiguous, contains but few members, who worship in our room when not occupied by us. The Catholics who have a house of worship in the town, do not keep at present a priest here and the house is not at present worshiped in. We have raised towards the support of Bro. 
Jones in the form of subscriptions Sixty Dollars, which it is beleived will be paid during the year, and in order that he may be comfortable in the discharge of his ministereal duties, it is proper that an appropriation of Two hundred \& fifty Dollars be made by your Society, for the support of him and his family for the ensueing year. Bro. Jones is our stated supply, and such is our weakness and the circumstances which surround us, that there is no arrangement for his installment in the course of the coming year.

The Post Office address of Bro. Daniel Jones is Keokuk Lee County Iowa Territory.

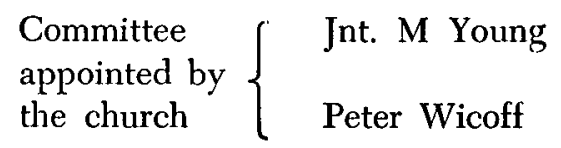

Quasqueton, Buchanan co. Iowa July 1st; 1854

Dear Sir: Yours in answer to my last duly received.

The past quarter has been one of no special changes in our church-Still no less than nine Congregational and Presbyterian professors have come to this place or vicinity to locate within a few days past- Some of these- particularly the later are very warm abolitionists from Michigan and may find a most congenial home among the come-outers or free Presbyterians of this place. Although our own church is antislavery in principle it is not prepared to abandon all old organizations.

The idea which is constantly held up before the people here by the Weslyans [Methodists] and free Presbyterians 9 that the established churches in the land are corrupt may have an influence to lead the world to believe that they are are better out of a church than in-even if they were christians. No less than five or six Weslyan ministers have passed

9 If the term Free Presbyterians is used in its purest sense it means those New School Presbyterians who formed a separate body in 1847 because of their antislavery views. Some radical churches in Ohio led the movement which never expanded outside the Middle West, and never become very large in membership. William Warren Sweet, The Story of Religion in America (2nd rev. ed., New York, 1950), p. 306. 
thro this place and preached during the past quarter. A two days meeting of the Weslyans aided by the free Presbyterians has just closed. Whether these come outers will exert an influence to disturb our church is yet to be seen. The foundation of our church house which is about forty feet square is now being laid and the bricks for the erection of its walls will probably be burnt in two weeks. The congregations here on the Sabbath continue to be quite large and respectable more so than in any place which I have ever lived in the West. The Sabbath School for size-the qualification of its Superintendents and teachers surpasses any with which I have become acquainted in the Western country. The Schoolhouse in which we have hitherto met is altogether too [small?] for us. We have secured for the present a large upper-room in a brick Store-house which we intend for Sabbath School and meeting purposes until our church is completed.

But for the sacrcity of building mateirals our town would have a large and sudden growth the present Summer. Eight small buildings have been erected here since my last report. My preaching as yet has been confined to this point, but I am beginning to feel that there is so much preaching here by other denominations that it will be my duty to occupy some other points in connection with this- I have recently had several invitations to occupy other points and make regular appointments. The Trustees of the Methodist church in Independence-the county seat, have invited me to make regular appointments in their house which $I$ intend to do if the church here will give their consent. Last Sabbath I preached in a neighborhood two miles from this place for the first time-and there is hope of organizing a Sabbath School here and making a point of regular preaching. Our prospects for a large and useful church are quite flattering although no additions were made during the past quarter. We now [are] in hope-and have reasons to believe that our hopes will not be disappointed. $\$ 75$, is now my due which I very much need as I am trying to collect materials for a shelter.

Yours in the best bonds.

\section{A. Wright}


Copyright of Annals of Iowa is the property of State of Iowa, by \& through the State Historical Society of Iowa and its content may not be copied or emailed to multiple sites or posted to a listserv without the copyright holder's express written permission. However, users may print, download, or email articles for individual use. 